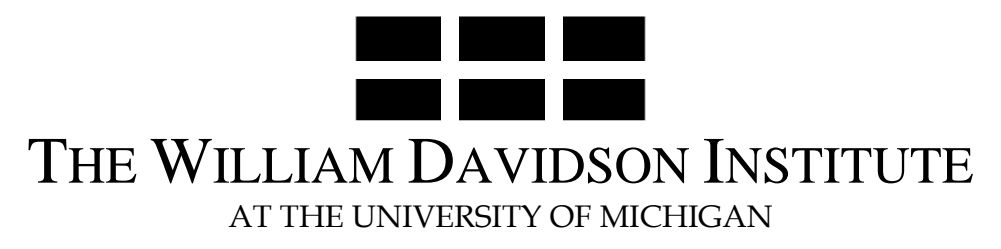

\title{
Real Exchange Rates in Small Open OECD and Transition Economies: Comparing Apples with Oranges?
}

By: Bálazs Égert, Kirsten Lommatzsch \& Amina Lahrèche-Révil

William Davidson Institute Working Paper Number 859 January 2007 


\title{
Real Exchange Rates in Small Open OECD and Transition Economies: Comparing Apples with Oranges?
}

Balázs Égert ${ }^{\ddagger}$

\author{
Kirsten Lommatzsch ${ }^{\dagger}$
}

\author{
Amina Lahrèche-Révil ${ }^{\S}$
}

\begin{abstract}
We find that productivity gains in tradables cause an appreciation of the real exchange rate via both tradable and nontradable prices in the CEE-5 and have no affect in the Baltic countries, while they lead to a depreciation of the real exchange rate of tradables in OECD economies that overcompensates the appreciation due to nontradable prices. Rising net foreign liabilities lead to a real appreciation in the Baltic countries instead of the expected depreciation found in OECD and CEE-5 countries. These differences are due to the different impact of the fundamentals on the real exchange rate depending on the time horizon studied.
\end{abstract}

JEL: C15, E31, F31, O11, P17

Keyword: real exchange rate, equilibrium exchange rate, productivity, tradables, Balassa-Samuelson effect

\footnotetext{
‡ Oesterreichische Nationalbank; EconomiX at the University of Paris X-Nanterre; and the William Davidson Institute. balazs.egert@oenb.at and begert@u-paris10.fr.

${ }^{\dagger}$ Corresponding author, DIW-Berlin; klommatzsch@diw.de.

§ CEPII; lahreche@cepii.fr

This is a substantially revised version of CEPII Working Paper 2004/15. We would like to thank László Halpern, Gian Maria Milesi-Ferretti, Paul Wachtel and two anonymous referees for their useful comments and suggestions. Special thanks go to Rena Muehldorf for excellent language advice. The views expressed in the paper do not necessarily reflect the opinion of the Oesterreichische Nationalbank or the European System of Central Banks (ESCB).
} 


\section{Introduction}

Most of the currencies of Central and Eastern European economies (CEE economies) have experienced substantial real appreciation since the outset of the transition process. The real exchange rate appreciated sharply in some countries already during the early years of transition, perhaps to correct an initial undervaluation. In addition, real exchange rates have appreciated strongly and quite steadily for most of the post-communist period. This phenomenon overlaps with strong catching-up economic growth following the transitional recession of the early 1990s, which is conventionally viewed to drive productivity-induced nontradable price inflation (BalassaSamuelson effect) and consequently a trend real appreciation. However, according to the consensus recently reached in the literature, the Balassa-Samuelson effect can account only for part of the observed appreciation (for an overview, see e.g. Égert, Halpern and MacDonald, 2005). The main reason for this is that Purchasing Power Parity (PPP) has not been holding for tradable goods either, as the real exchange rate deflated by producer prices has also recorded a trend appreciation in most of the transition economies (Figure 1).

At the same time, transition economies have been running sometimes large current account deficits. Although this could be viewed as a logical consequence of the real appreciation, large current account deficits may be sustainable in the medium run. The reason for this is that investment needed for catching-up growth could not be fully financed by domestic savings. As a result, current account deficits can be thought of as natural during catching-up growth. Capital inflows including large FDI, attracted by bright domestic growth prospects and providing longterm financing of current account deficits, can be reflected in a real appreciation of the domestic currency.

However, over the longer run, capital inflows may generate large income payments to foreign countries. As witnessed in the income balance of a number of transition economies, payments of interest, profits and dividends have gained in importance in recent years, resulting in large account deficits (Figure A2 in the Appendix) in some cases. This has raised concerns regarding long-term external sustainability. Indeed, growing foreign debt may over the longer run require a real depreciation of the currency, as suggested by the "transfer problem" and as documented recently for OECD countries (Lane and Milesi-Ferretti, 2004).

\footnotetext{
${ }^{1}$ This contrasts with the findings of the literature for OECD countries, for which changes in the real exchange rate of the open sector seem to weaken rather than strengthen the effect of relative price movements on the overall real exchange rate (Lee and Tang, 2003).
} 
Figure 1. (Log) Real Exchange Rates in Transition Economies, 1990 to 2004
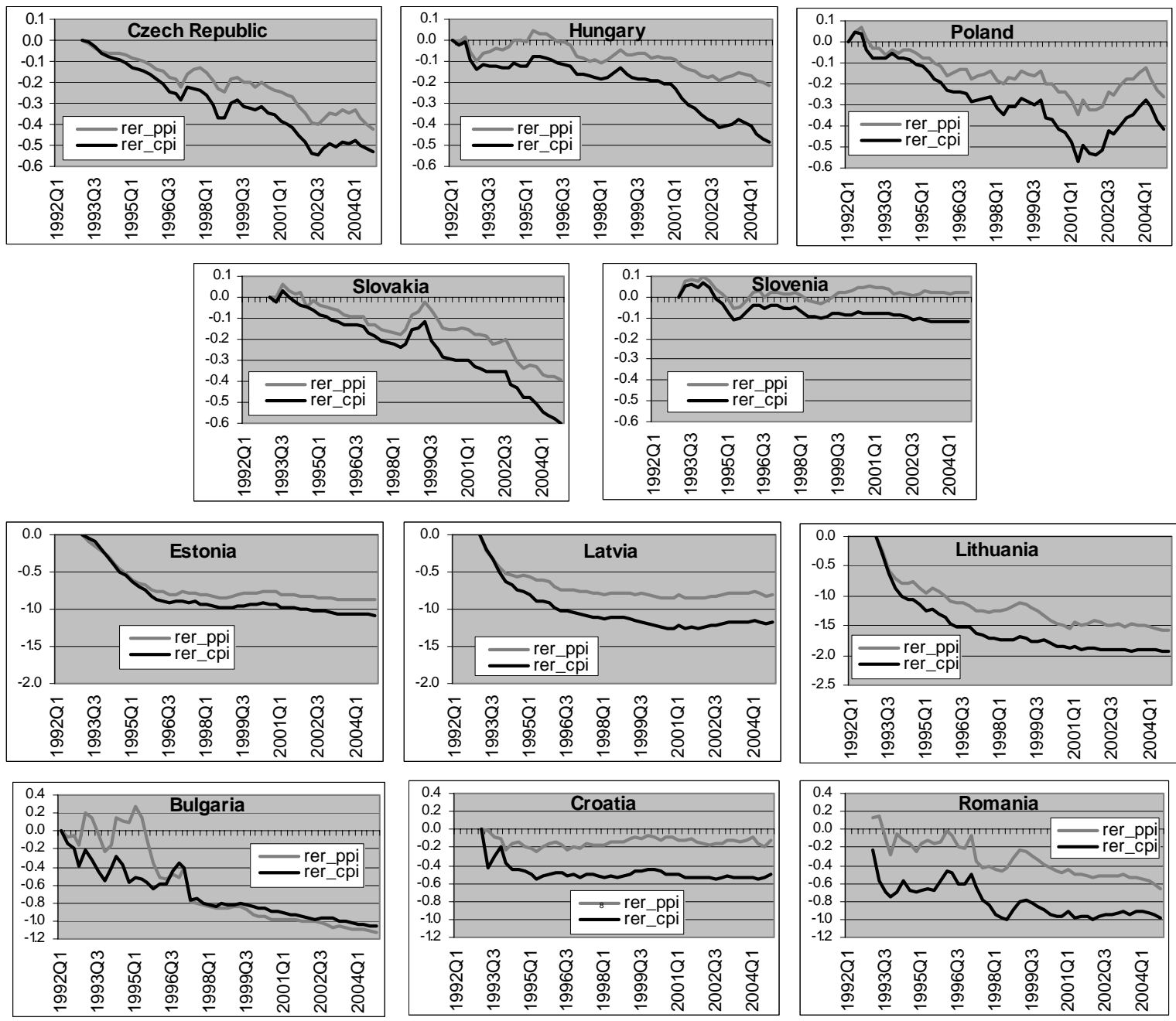

Source: Authors' calculations based on data described in Section 3.2.

In this paper, we investigate the impact of productivity and net foreign assets on the real exchange rate of 11 transition economies. Because these variables can have a different influence on the real exchange rate of transition economies than on that of OECD countries, a panel of small, open OECD countries is used as a benchmark for the results obtained for transition economies. We uncover substantial parameter heterogeneity for both variables between the two groups of countries because productivity and net foreign assets have a different impact on the real exchange rate depending on the time horizon studied.

Parameter heterogeneity is indeed an important finding in the light of the proposition that out-ofsample panel estimates ${ }^{2}$ may be superior to in-sample panel estimates for transition economies, ${ }^{3}$

\footnotetext{
${ }^{2}$ In-sample and out-of-sample estimates are defined here in terms of country coverage. More specifically, out-of-sample measures of the equilibrium exchange rate for a given country are based on exchange-rate equations estimated for a sample from which this country is excluded. Conversely, in-sample measures are derived from equations estimated on a geographical sample including the country of interest.

${ }^{3}$ That is, estimation results obtained for a group of OECD countries should be applied to transition economies.
} 
because in the presence of initial undervaluation, in-sample panels produce biased estimates (Maeso-Fernandez, Osbat and Schnatz, 2005) ${ }^{4}$. However, as we show, the out-of-sample approach cannot, by its very nature, account for possible parameter heterogeneity between the transition countries and more developed OECD economies related to the catching-up process.

The remainder of the paper is organized as follows: Section 2 presents the theoretical background. Section 3 describes the data and the estimation methods. Estimation results are then presented in Section 4. Finally, Section 5 concludes.

\section{Theoretical Background}

\subsection{Real Exchange Rate Decomposition}

It is convenient to start with a decomposition of the real exchange rate. Considering that the CPI is decomposed into tradable and nontradable goods, with $\alpha$ and $(1-\alpha)$ being the respective share of tradable and nontradable goods in the CPI, the real exchange rate can be split into the two major components shown below:

$$
q=\underbrace{e+p^{T^{*}}-p^{T}}_{\begin{array}{c}
\text { real exchange rate of } \\
\text { the tradable sector }
\end{array}}-\underbrace{(1-\alpha)\left(p^{N T}-p^{T}\right)-\left(1-\alpha^{*}\right)\left(p^{N T^{*}}-p^{T^{*}}\right)}_{\begin{array}{c}
\text { ratio of the domestic to the foreign relative price of } \\
\text { nontradablegoods }
\end{array}}
$$

Where $q$ denotes the real exchange rate, $e$ the nominal exchange rate, defined as domestic

currency units over one unit of foreign currency ${ }^{5}, p^{T}$ the price of tradables and $p^{N T}$ the price of nontradables. Asterisks refer to the foreign country, and all variables are taken in logs. The first term is the real exchange rate for the open sector, which contains the nominal exchange rate and the ratio of foreign to domestic tradable prices. The second term is the ratio of domestic to foreign relative prices of nontradable goods. Such a decomposition allows one to separate the factors that influence the real exchange rate of the open sector (and hence the current account via the trade balance) from the ones that are related to price developments in the nontradable sector.

\subsection{Productivity and Equilibrium Real Exchange Rate}

\subsubsection{The Balassa-Samuelson Effect: Real Appreciation Due to Nontradable Prices}

The most often used model of the impact of productivity growth on nontradable goods prices (second term in equation 1) and the real exchange rate during economic catching-up is the Balassa-Samuelson model. This model assumes that the economy can be split into sectors producing tradable and nontradable goods. Purchasing power parity is supposed to hold for the

\footnotetext{
${ }^{4}$ The equilibrium real appreciation during the transition and catching-up process could be overestimated, if the observed real appreciation reflects the adjustment toward equilibrium due to initial undervaluation.

${ }^{5}$ Hence, an increase (decrease) in the exchange rate reflects a depreciation (appreciation).
} 
open sector, i.e. expressed in the same currency unit, tradable prices are the same across countries. At the same time, the level of wages in the open sector is given by the latter's productivity level. This implies that less developed economies with lower levels of productivity have lower wages in the open sector than more developed economies do. This has important implications for the price level of nontradable goods. If wages tend to equalize across the open and sheltered sectors, and prices in the sheltered sector are determined mainly by wage costs, the price of nontradable goods will be lower in the low-productivity country than in high-productivity countries. However, if the less developed country catches up with the more developed one by recording high productivity increases in its open sector, it will also experience higher inflation rates for nontradable goods due to the wage equalization process across the economy. As a result, the overall inflation differential, which is fueled by productivity gains in the open sector, will be reflected in the appreciation of the real exchange rate.

\subsubsection{New Open Economy Macroeconomics Models: Real Depreciation due to Tradable}

\section{Prices}

New Open Economy Macroeconomics (NOEM) models have recently demonstrated that the change in the relative price of nontradables need not be the only consequence of higher productivity growth in the open sector. They focus on the real exchange rate of the open sector (first term in equation 1) and try to explain the empirical failure of PPP for the open sector. ${ }^{6}$ Based on variants of general equilibrium models with imperfect substitutability and product variety à la Dixit and Stiglitz (1977), MacDonald and Ricci (2002), Benigno and Thoenissen (2003) and Unayama (2003) show that an increase in productivity in the tradable sector (and in variety) leads to a depreciation of the real exchange rate of the open sector through the terms-of-trade channel. In the presence of home bias, productivity gains in the open sector have a negative effect on the price of home-produced tradables when compared to the price of foreign-produced goods, which yields a real depreciation. Whether or not the real exchange rate of the whole economy depreciates or appreciates in the aftermath of an increase in productivity depends on whether the depreciation of the real exchange rate of the open sector is outweighed by the real appreciation induced by the Balassa-Samuelson effect (i.e. on the magnitude of the two effects and the weights of the tradable and nontradable goods in the consumer price index). ${ }^{7}$

\footnotetext{
${ }^{6}$ The empirical literature has been long stressing that nominal exchange rates and thus the real exchange rate of the open sector dominate changes in the overall real exchange rate of industrialized countries (Mussa, 1986; Engel, 1993, 1999; and Monacelli, 2004). Canzoneri, Cumby and Diba (1999) provide econometric evidence that PPP cannot be verified for the open sector for a number of OECD countries, especially when the U.S. dollar is used as the numeraire currency.

${ }^{7}$ For instance, MacDonald and Ricci (2002) find that productivity gains lead to an overall appreciation of the real exchange rate, while Benigno and Thoenissen (2003), on the basis of calibrated coefficients, show that an increase in productivity in the open sector yields an overall depreciation of the real exchange rate because its negative impact on the real exchange rate in the open sector (depreciation) outweighs its positive impact on the relative price of nontradables (appreciation).
} 


\subsubsection{Transition Economies: Real Appreciation due to Tradable Prices}

For transition economies, the relation between productivity and the real exchange rate in the open sector is affected by yet another factor. Given the uncompetitive and quantity-oriented supply of planned economies, the process of economic transformation from plan to market requires - in addition to a broadening of the variety of the goods produced - a major shift toward the production of better quality goods with higher value added and higher prices. In particular, the sizeable inflow of FDI enables the countries to adopt technologies closer to the technological frontier. Therefore, quality improvements, which are a common feature of all market economies, are much more pronounced in transition economies. As long as quality adjustment is insufficient, the upgrading of supply will show up in both inflation rates and GDP growth due to productivity gains.

The price-increasing effect of quality improvements is furthermore amplified by an increase in reputation and by a shift of preferences toward home-produced goods ${ }^{9}$ both in the foreign and in the domestic markets, which allow higher prices to be set for goods produced in the home economy both in the foreign and in the domestic markets (Égert and Lommatzsch, 2004).

In sum, quality improvements, and the associated rise in reputation and better marketing, are reflected in a positive tradable inflation differential (first term in equation 1) and, subsequently, in an appreciation of the real exchange rate. Given that productivity increases in the open sector of transition economies largely mirror the impact of inflowing FDI and the ensuing quality improvement, an increase in productivity in the open sector is associated with a real appreciation of the real exchange rate of the open sector. ${ }^{10,11}$

\subsection{Current Account, Net Foreign Assets and the Equilibrium Exchange Rate}

Intertemporal models of the current account suggest that current account deficits can be a natural phenomenon of the catching-up growth process. ${ }^{12}$ According to this class of models, consumers

\footnotetext{
${ }^{8}$ An increase in the quality of goods implies, theoretically, a rise in real income and the price level without a loss of purchasing power (i.e. without inflation).

${ }^{9}$ The outset of the transition process was characterized by a run to foreign goods (foreign goods bias) as consumer sought better quality and more variety.

${ }^{10}$ In transition economies, such gains in non-price competitiveness are best captured by changes in productivity, because technology is mostly imported from abroad via FDI. While R\&D expenditures are often used as a measure of non-price competitiveness for industrialized countries, they seem less appropriate for transition economies, since R\&D is mostly produced abroad and then imported by the transition economies via FDI.

${ }^{11}$ Recall that higher productivity growth in the open sector might also lead to real depreciation due to prices of tradables with higher variety and efficiency

${ }^{12}$ In these models, the optimal path of the current account is given as the result of savings and investment decisions in an economy facing an intertemporal budget constraint (Obstfeld and Rogoff, 1994). Because of capital mobility across countries and because of cross-country differences in time preferences and real returns, international lending and borrowing can increase the utility of consumers by means of consumption
} 
smooth consumption over time, which results in current account deficits in countries with higher growth (potential). The debt increases due to current account deficits in the early years. The accumulation of foreign debt is followed by debt repayment in subsequent periods.

While sustainable current account imbalances can be rather large, as suggested by the intertemporal model, no size of the current account deficit is safe even if growth potential is high. In practice, particular risks can arise with regard to the sources of financing current account deficits, the stability of the financial system or government policies (Roubini and Wachtel, 1999). Shocks to the domestic or foreign economies can make the financing of the current account difficult, so that sudden adjustments of the current account may become necessary. This correction can be achieved most easily with a real depreciation (Chinn, 2005). In addition, according to the “transfer problem," countries with foreign debt need to run trade surpluses to service their debt, which, once again, is most easily achieved with a real depreciation. Recent intertemporal models with optimizing agents develop this link between net foreign assets and the real exchange rate, where the income transfer is connected with a depreciated currency in real terms in the country servicing the debt (Lane and Milesi-Ferretti, 2002, and Thoenissen, 2005). This relation is largely confirmed in empirical studies (Lane and Milesi-Ferretti, 2004, Gagnon, 1996, and Alberola et al., 1999).

Overall, countries with higher growth potential can benefit from running current account deficits for some time; however, these have to correspond to their growth prospects. Otherwise, an adjustment of the real exchange rate becomes necessary. At the same time, a rise in foreign debt as a result of current account deficits puts pressure on the real exchange rate to depreciate in the long run.

\section{Estimation Issues}

\subsection{Reduced-Form Equations}

A number of reduced-form specifications are estimated in order to disentangle the different channels through which productivity influences the real exchange rate and to compare whether or not productivity and net foreign assets affect the real exchange rate in a similar manner in OECD and transition economies.

First, the effect of productivity improvements on the real exchange rate of the open sector is assessed as in equation (2), where the producer price index (PPI)-deflated real exchange rate $\left(q^{P P I}\right)$ is regressed on productivity and net foreign assets:

smoothing. The equilibrium condition in this setting is that no country can increase its debt forever. In a finite period setting, foreign debt has to be repaid in the last period; while it has to converge to zero in the limit when assuming infinite periods. 


$$
q^{P P I}=f(\stackrel{+/-}{\text { prod }, \text { nfa }})
$$

where an increase in productivity would lead to a real depreciation (+ sign) if predictions of NOEM models hold true. By contrast, productivity gains are expected to yield a real appreciation (- sign) if they capture quality changes and upgraded supply capacities in the open sector.

In a second step, the CPI-based real exchange rate is regressed on the relative price of nontradables to that of tradables ( $\mathrm{rel}$ ) and net foreign assets:

$$
q^{C P I}=f\left({ }_{\text {rel }, ~}^{+/-} \text {ffa }\right)
$$

where an increase rel is expected to lead to a real appreciation. It is common practice in the literature to use the CPI-to-PPI ratio as a proxy for productivity to account for the BalassaSamuelson effect. In such a case it is assumed that the relationship between the productivity differential and the relative price holds as suggested by the Balassa-Samuelson model. ${ }^{13}$

Third, productivity and relative prices are considered simultaneously in one single specification to see whether the productivity variable and the relative price variable convey a different set of information. If they both enter the equation significantly, the productivity variable would reflect the effect on tradable prices (equation (2)), whereas the CPI-to-PPI ratio would stand for relative price adjusment (equation (3)) :

$$
q^{C P I}=f(\stackrel{+/-}{\text { prod }}, \stackrel{-}{\text { rel }}, \stackrel{+/-}{n f a})
$$

Finally, we consider the real exchange rate deflated using the CPI $\left(q^{C P I}\right)$ on the one hand, and productivity ( prod ) and net foreign assets ( $n f a$ ) on the other, given in equation (5):

$$
q^{C P I}=f(\stackrel{+/-}{\text { prod }}, \stackrel{+/-}{\text { nfa }})
$$

The reason why we also test this specification is to see the overall impact of productivity on the real exchange rate, i.e. whether the depreciation channel predicted by NOEM models dominates the appreciation due to changes in relative price, if both channels are at work. As a results, the sign of the productivity variable may be either negative or positive.

The sign of net foreign assets is not unambiguous, either. The differences in the sign of the net foreign assets will be related to the investigated time horizon. In the longer term, any increase in

\footnotetext{
${ }^{13}$ There are, however, two problems. First, productivity gains can affect the real exchange rate via different channels (via tradable and nontradable prices) and, second, the CPI-to-PPI ratio also measures the impact of factors other than the Balassa-Samuelson effect: (a) higher demand for nontradable goods because of higher income; (b) indirect taxes (which are included in the calculation of the CPI but not in the calculation of the PPI, the latter referring to producer prices before adding indirect taxes); (c) the adjustment of regulated prices (which most often concerns nontradables); and (d) more difficulties in adjustment for quality changes of nontradables than tradables.
} 
NFA is associated with an appreciation of the real exchange rate (- sign ). However, the sign is positive over the medium term if a decrease in net foreign assets (debt creation) is linked to the appreciation of the real exchange rate. This may apply to countries that experience a rapid change in their growth prospects, as was the case for the transition countries that successfully started the transition process.

\section{2. $\quad$ Data Sources and Definitions}

The dataset covers 26 countries, of which 15 are small, open, industrialized OECD economies ${ }^{14}$ considered in the benchmark panel (1) and of which 11 are transition economies from Central and Eastern Europe $^{15}$ (panel 2). Because we are concerned primarily with real exchange rates for the transition economies, we divided the panel of 11 transition economies in order to account for possibly significant differences between the transition countries. For example, Bulgaria and Romania are less advanced in their reforms than the new EU Member States, and the Baltic countries have experienced higher real appreciation as compared to the other transition economies. Therefore, two further panels were formed: (3) the CEE-5, and (4) the three Baltic countries. The data spans the period from 1973 to 2004 for panel (1) ${ }^{16}$. However, for some of the countries, some of the series begin later. Regarding transition economies, the datasets span the period from 1993 to 2004. For Bulgaria, Hungary and Poland, the data series start in 1992. All data are quarterly and transformed into logs, except for net foreign assets. The data are drawn mainly from the International Financial Statistics (IFS) of the IMF, and, wherever not available from this source, are completed from the Main Economic Indicators of the OECD, NewCronos of Eurostat, diverse databases of The Vienna Institute for Comparative Economic Studies (WIIW) and national statistics.

The real effective exchange rate is a weighted average of the real exchange rate vis-à-vis Germany, France, Italy, the U.K., the U.S.A. and Japan. The weights allocated to the individual benchmark countries are given by trade patterns based on data obtained from the IMF Direction of Trade statistics. Weights are allowed to change. Average labor productivity in industry is computed as industrial production to employment in industry. The relative price of nontradables to tradables is approximated by the CPI-to-PPI ratio. All variables are calculated as the domestic to foreign series ratio. Net foreign assets are constructed as cumulated current account deficits/surpluses expressed in terms of GDP.

\footnotetext{
${ }^{14}$ Austria, Australia, Belgium, Denmark, the Netherlands, Sweden, Canada, Finland, Greece, Ireland, Portugal, Spain, New Zealand, South Africa and South Korea. Although South Africa is not an OECD country, its economic structure may be considered for the most of the sample as rather similar to that of Australia and New Zealand.

${ }^{15}$ Bulgaria, Croatia, the Czech Republic, Hungary, Poland, Slovakia, Slovenia, Estonia, Latvia, Lithuania and Romania.

${ }^{16}$ Exceptions are Austria (1976-2004), Belgium (1981-2003), New Zealand (1977-2004), South Korea (1980-2004), Portugal (1990-2004) and Spain (1977-2004).
} 


\subsection{Econometric Issues}

The first step is to check whether or not the series are stationary in levels. If the series turn out to be nonstationary in levels but stationary in first differences, the coefficients of the long-term relationships are derived by using the mean group of individual estimates based on the errorcorrection specification of the ARDL process proposed by Pesaran, Shin and Smith (1999). The error correction form of the ARDL model is given for panel member $i$ as shown in equation (6) where the dependent variable in first differences is regressed on the lagged values of the dependent and independent variables in levels and first differences:

$$
\Delta Y_{i, t}=\beta_{i, 0}+\rho\left(Y_{i, t-1}+\sum_{h=1}^{n} \beta_{i, h} X_{i, t-1}\right)+\sum_{j=1}^{l_{1}} \eta_{i, j} \Delta Y_{i, t-j}+\sum_{h=1}^{n} \sum_{j=0}^{l_{2}} \gamma_{i, j} \Delta X_{i, t-j}+\varepsilon_{i, t}
$$

where $l 1$ and $l 2$ are the maximum lags. ${ }^{17}$ The error correction terms obtained from the mean group estimators proposed by Pesaran, Shin and Smith. (1999) are used as tests for cointegration. A negative and statistically significant error correction term is taken as evidence for the presence of cointegration.

\section{Results}

\subsection{Productivity}

Econometric estimations for transition economies are carried out for three different panels containing (a) all 11 transition economies (CEE-11), (b) the 5 Central and Eastern European countries (CEE-5; the Czech Republic, Hungary, Poland, Slovakia, Slovenia) and a panel containing the three Baltic states (B-3). This division turns out to yield some important insights for the behavior of different groups of transition economies.

Table 1 shows that the error correction terms are negative and highly significant for all specifications, indicating the presence of a cointegration vector for all tested equations. The error correction terms are around -0.1 for the OECD countries, about -0.2 for the B- 3 countries and in the neighborhood of -0.3 for the CEE- 5 economies, implying higher speeds of adjustments for transition economies than for the OECD countries.

As shown in Tables 2a and 2b, a rise in the productivity variable leads to a real appreciation of the exchange rate of the open sector for the CEE-11 and for the CEE-5. This finding provides strong evidence in favor of the hypothesis that productivity growth in the CEE- 5 transition economies is related to quality improvement and a shift toward goods of higher technological content. This

\footnotetext{
${ }^{17}$ The maximum lag length is set to three lags. An exception is the specification including three regressors for the transition economies, where a maximum lag length of 2 is employed.
} 
stands in sharp contrast to results obtained for the OECD countries, where productivity increases result in a real depreciation - in line with the theoretical predictions of the NOEM models.

An increase in relative prices yields an appreciation of the CPI-based real exchange rate, much as observed for OECD countries. This gives credit to the view that the Balassa-Samuelson effect and other relative price adjustments are sources of the observed real appreciation. However, it should be also emphasized that this is only an additional factor to the tradable price-based real appreciation in the CEE-5.

For the CEE-5 economies, the extended specification confirms that the productivity variable and relative prices do not carry the same set of information, as both variables enter the equations with a significant negative sign, indicating that both variables produce an appreciation of the real exchange rate. It is also no surprise to find that the overall impact of productivity on the CPI-based real exchange rate is negative, i.e. a rise in productivity causes a real appreciation, as the effects of quality improvements and relative price adjustments add up. This finding, once again, contrasts with the results obtained for the OECD panel, where the productivity variable is statistically significant for the equation including the CPI-based real exchange rate and has a positive sign. This means that productivity increases cause the overall real exchange rate to depreciate, and that the depreciation coming from the real exchange rate of the open sector largely overcompensates the appreciation due to the Balassa-Samuelson effect and to other types of relative price adjustments. $^{18}$

At the same time, no statistically robust relations could be established between productivity, relative prices and the real exchange rate for any of the four specifications for the three Baltic countries that would indicate that quality improvements in the open sector and relative price adjustments are less important (or statistically insignificant) for real exchange rate determination than for other transition economies. ${ }^{19}$ This is a consequence of the delayed start of the transition process. While the CEE-5 economies launched economic reforms already in the early 1990s, the transition process in the Baltic states started only after independence, political consolidation and macroeconomic stabilization had been achieved by the mid-1990s. Productivity growth reflecting rapid quality improvement of manufactured goods may have become important only quite recently.

\footnotetext{
${ }^{18}$ The extended specification including both the productivity and the relative price variables confirms the coexistence of the two channels: both variables are significant and bear the same sign as in the two baseline specifications - an increase in the productivity of the open sector is linked to a real depreciation while an increase in relative prices yields an appreciation of the real exchange rate.

${ }^{19}$ Kuzmina and Lobakovs (2004) find it difficult to establish convincingly the Balassa-Samuelson effect on the real exchange rate for Latvia. Égert (2005) could establish a statistically significant relationship between the productivity variable and the real exchange rate for Estonia only after having eliminated the regulated price component of the CPI indices and after having adjusted the share of different groups of goods and services in the domestic and foreign CPI baskets.
} 
Table 1. Error Correction Terms from the Mean Group Estimator Estimations

\begin{tabular}{lll}
\hline & $q^{P P I}=f($ prod,$n f a)$ & $q^{C P I}=f($ rel,$n f a)$ \\
\hline OECD & $-0.134^{* * *}$ & $-0.096^{* * *}$ \\
CEE-11 & $-0.329^{* * *}$ & $-0.235^{* * *}$ \\
CEE-5 & $-0.296^{* * *}$ & $-0.284^{* * *}$ \\
B-3 & $-0.200^{* * *}$ & $-0.176^{* * *}$ \\
\hline & $q^{C P I}=f($ prod $, r e l, n f a)$ & $q^{C P I}=f($ prod,$n f a)$ \\
\hline OECD & $-0.138^{* * *}$ & $-0.109^{* * *}$ \\
CEE-11 & $-0.254^{* * *}$ & $-0.226^{* * *}$ \\
CEE-5 & $-0.303^{* * *}$ & $-0.223^{* * *}$ \\
B-3 & $-0.149^{* * *}$ & $-0.171^{* * *}$
\end{tabular}

Note: *,* and *** indicate statistical significance at the $10 \%, 5 \%$ and $1 \%$ levels, respectively.

Table 2a. Coefficient Estimates from the Mean Group Estimator Estimations

\begin{tabular}{lllll}
\hline & \multicolumn{2}{l}{$q^{P P I}=f($ prod,$n f a)$} & \multicolumn{2}{l}{$q^{C P I}=f($ rel,$n f a)$} \\
\hline & prod & $n f a$ & rel & $n f a$ \\
OECD & $0.265^{* * *}$ & $-0.006^{* * *}$ & $-0.226^{* * *}$ & $-0.005^{* *}$ \\
CEE-11 & $-0.740^{* * *}$ & -0.005 & $-1.176^{* *}$ & $0.0003^{* *}$ \\
CEE-5 & $-0.732^{* * *}$ & $-0.004^{*}$ & $-2.649^{* * *}$ & -0.001 \\
B-3 & -0.069 & $0.004^{* * *}$ & 0.263 & $0.005^{* *}$ \\
\hline
\end{tabular}

Note: As for Table 1.

Table 2b. Coefficient Estimates from the Mean Group Estimator Estimations

\begin{tabular}{llllll}
\hline & \multicolumn{2}{c}{$q^{\text {CPI }}=f($ prod, rel,$n f a)$} & & \multicolumn{2}{c}{$q^{C P I}=f($ prod,$n f a)$} \\
\hline & prod & rel & $n f a$ & prod & $n f a$ \\
OECD & $0.243^{* * *}$ & $-0.697^{* * *}$ & $-0.005^{* * *}$ & $0.431^{* * *}$ & $-0.010^{* *}$ \\
CEE-11 & $-0.402^{* * *}$ & $-0.458^{* *}$ & -0.001 & $-0.435^{* * *}$ & $0.003^{*}$ \\
CEE-5 & $-0.704^{* * *}$ & $-1.682^{* * *}$ & $-0.008^{*}$ & $-0.874^{* * *}$ & 0.001 \\
B-3 & 0.017 & 0.965 & $0.005^{* *}$ & 0.211 & $0.005^{* * *}$ \\
\hline \multicolumn{5}{c}{ Note: As for Table 1.}
\end{tabular}

\subsection{Net Foreign Assets}

The results reported in Tables 2a and 2b indicate strong heterogeneity across transition economies for net foreign assets, too. While the relationship between net foreign assets and the real exchange rate is systematically positive for all specifications for the Baltic countries (an increase in net foreign liabilities leads to an appreciation of the real exchange rate), the tests reveal a mostly negative sign for the group of CEE-5 economies, implying that any increase in net foreign 
liabilities yields a depreciation of the real exchange rate. For the panel including all 11 CEE transition economies, the estimated coefficients turn out to be statistically insignificant, because the results for the CEE-5 and B-3 seem to cancel each other out.

Based on our results, we argue that the sign on net foreign assets may be connected with the studied time horizon, different initial conditions and differences in the perceived growth potential of the economies. The three Baltic countries started economic transformation with nearly no foreign debt, and their growth prospects ameliorated significantly after they had become independent and had opened up to foreign capital. Since the mid-1990s, they have recorded the highest growth rates in the region, reaching $7 \%$ a year since 2000. They have also registered the highest current account deficits (up to above 12\% in Estonia in 2003 and 2004), which can be to a large extent traced back to large trade deficits. Although income payments have become quite sizeable at least in, the pressure toward currency depreciation may be reduced also due to sustained reinvestment of profits. The Baltic States could thus fit into the picture of a sudden and large change in the growth potential, which provokes substantial trade deficits in the early years. At least part of the large deficits can therefore be thought of as an equilibrium phenomenon (see also Bussière, Fratzscher and Müller, 2004; Hansen and Hansen, 2004; and Bems and Jönsson, 2005).

The situation in the CEE-5 countries seems to be different. They recorded large trade and current account deficits in the mid-1990s. However, a consolidation of the trade balance based on pronounced export growth has been observed since 2000. Current account deficits started to decline or have increasingly become dominated by income payments ${ }^{20}$ due to high external debt inherited from the communist era in some countries (Hungary and Poland) and due to foreign firms' repatriation of profits to their country of origin.

Therefore, our empirical evidence gives support to the idea that countries with higher growth potential may run current account deficits for some time provided current account deficits are in line with growth prospects. However, this effect will be reversed later on, with debt servicing becoming the dominant effect of net foreign assets (or debt) on the real exchange rate. The reason why the results indicate a positive relationship for the Baltic countries and a negative one for the CEE-5 is that the Baltic countries may still be at the early stage of the catching-up process, while the CEE-5 are already at a more advanced stage. The long-term and theoretically predicted relationship can be also observed for our benchmark panel of OECD countries, as the net foreign assets variable is found to be highly significant and to have a negative sign across all specifications, implying that an increase in net foreign assets leads to an appreciation of the real exchange rate.

\footnotetext{
${ }^{20}$ Income payments reached 5\% of GDP in 2004 in the Czech Republic and in Hungary.
} 


\section{Conclusion}

This study investigated determinants of the real exchange rate, in particular the role of productivity, relative prices and net foreign assets for a set of transition economies of Central and Eastern Europe and a group of small OECD countries. Our results reveal substantial differences across OECD countries and transition economies on the one hand, and even among transition economies, on the other hand.

First, unlike for OECD countries, an increase in productivity turns out to yield an appreciation of the real exchange rate of the open sector in the CEE-5 economies. This could reflect major improvements in the quality and reputation of manufactured goods, which constitute the basis of the catching-up process in these countries. The relative price adjustment, which is found to lead to an appreciation as in the OECD countries, is an additional channel through which productivity causes the real exchange rate to appreciate in the CEE- 5 economies. For OECD countries, while relative price adjustments induce a real appreciation, productivity gains lead to a depreciation of the real exchange rate in the open sector, providing support for the class of NOEM models which turn out to dominate the appreciation induced through relative prices, as an increase in productivity is connected with a depreciation of the economy-wide real exchange rate. By contrast, neither productivity nor relative prices enter significantly any of the tested equations for the Baltic countries.

Second, the sign on net foreign assets obtained for the Baltic countries shows that higher debt leads to an appreciation of the real exchange rate, while for the CEE-5, the signs tend to be consistent with the long-run effect predicted by theory and also confirmed for the sample of OECD economies, i.e. an increase in net foreign assets tends to be associated with a long-term appreciation of the real exchange rate. These differing results are connected to the different time horizon and to the different stages of the catching-up process. In particular, as the positive sign on net foreign assets is a medium-term or transitory phenomenon, it will most probably evaporate and reverse over time for the Baltic countries as they move forward in the catching-up process and accumulate high levels of foreign debt.

To summarize, in this study, we have uncovered substantial differences across OECD and transition economies with regard to the impact of productivity and net foreign assets on the real exchange rate. Our results have important implications especially in the light of the proposition that out-of-sample panels composed of OECD countries should be preferred over in-sample panels and time series for assessing the equilibrium exchange rate of transition economies (MaesoFernandez, Osbat and Schnatz, 2005). Although the out-of-sample approach remedies pitfalls related to the initial undervaluation of the transition economies' currencies, it creates new ones because it produces estimates for the long-run equilibrium exchange rate. Such estimates could be inappropriate for policy purposes mainly because they ignore that the medium-term adjustment 
process toward the longer-term equilibrium can entail different relations between the real exchange rate and its determinants. Most importantly, in view of the approaching enlargement of the euro area and the final fixing of nominal exchange rates, an equilibrium entry rate determined on the basis of the long-term relationships of the OECD countries could imply entry rates out of tune with the medium-term equilibrium rate. The out-of-sample approach may become more appropriate later on when transition economies will have caught up with the developed countries, and this will be reflected in the behavior of their real exchange rate. Paradoxically, the out-ofsample approach may no longer be needed then, as initial undervaluation will belong to the remote past. 


\section{References}

Alberola, E., Cervero, S. G., Lopez, H. and Ubide, A., 1999. Global Equilibrium Exchange Rates: Euro, Dollar, “Ins,” “Outs,” and Other Major Currencies in a Panel Cointegration Framework. IMF Working Paper No. 175.

Bems, R., Jönsson, K., 2005. Trade Deficits in the Baltic States: How Long Will the Party Last? Review of Economic Dynamics (forthcoming).

Benigno, G., Thoenissen, C., 2003. Equilibrium Exchange Rates and Capital and Supply Side Performance. Economic Journal 113(486), 103--124.

Bussière, M., Fratzscher, M., Müller, G.J., 2004. Current Account Dynamics in OECD and EU Acceding Countries - An Intertemporal Approach. ECB Working Paper No. 311.

Canzoneri, M.B., Cumby, R.E., Diba, B., 1999. Relative Labour Productivity and the Real Exchange Rate in the Long-Run: Evidence for a Panel of OECD Countries. Journal of International Economics 47, $245--266$.

Chinn, M. D., 2005. A Primer on Real Effective Exchange Rates: Determinants, Overvaluation, Trade Flows and Competitive Devaluation. NBER Working Paper No. 11521.

Dixit, A.K., Stiglitz, J., 1977. Monopolistic Competition and Optimum Product Diversity. American Economic Review 67(3), 297--308.

Égert, B., 2005. The Balassa-Samuelson Hypothesis in Estonia: Oil Shale, Tradable Goods, Regulated Prices and Other Culprits. The World Economy 28 (2), 259--286.

Égert, B., Lommatzsch, K., 2004. Equilibrium Exchange Rates in the Transition: The Tradable Price-Based Real Appreciation and Estimation Uncertainty. William Davidson Institute Working Paper No. 676.

Égert, B., Halpern, L., MacDonald, R., 2005. Equilibrium Exchange Rates in Transition Economies: Taking Stock of the Issues. CEPR Discussion Paper No. 4809 and Journal of Economic Surveys (forthcoming).

Engel, C., 1993. Exchange Rates and Relative Prices: An Empirical Investigation. Journal of Monetary Economics 32(1), 32--50.

Engel, C., 1999. Accounting for US Real Exchange Rate Changes. Journal of Political Economy 107(3), 507--38.

Gagnon, J. E., 1996. Net Foreign Assets and Equilibrium Exchange Rates: Panel Evidence. Board of Governors of the Federal Reserve System, International Finance Discussion Paper No. 574.

Hansen, J.D., Hansen, M., 2004. Are the Current Account Deficits in the Baltic States Sustainable? Baltic Journal of Economics 3(1), 5--24.

Kuzmina, I., Lobakovs, A., 2004. The Impact of Sector Productivity Differentials on Inflation and the Real Exchange Rate: An Estimation of the Balassa-Samuelson Effect in Latvia. Stockholm School of Economics in Riga Working Paper No. 10.

Lane, P. M., Milesi-Ferretti, G.M., 2002. External Wealth, the Trade Balance and the Real Exchange Rate. European Economic Review 46(6), 1046--1071. 
Lane, P. M., Milesi-Ferretti, G.M., 2004. The Transfer Problem Revisited: Net Foreign Assets and Real Exchange Rates. Review of Economics and Statistics 86(4), 841--857.

Lee, J., Tang, M. K., 2003. Does Productivity Growth Lead to Appreciation of the Real Exchange Rate? IMF Working Paper No. 154.

MacDonald, R., Ricci, L., 2002. Purchasing Power Parity and New Trade Theory. IMF Working Paper No. 32.

Maeso-Fernandez, F., Osbat, C., Schnatz, B., 2005. Pitfalls in Estimating Equilibrium Exchange Rates for Transition Economies. Economic Systems 29(2), 130--143.

Monacelli, T., 2004. Into the Mussa Puzzle: Monetary Policy Regimes and the Real Exchange Rate in a Small Open Economy. Journal of International Economics 62, 191--217.

Mussa, M., 1986. Nominal Exchange Rate Regimes and the Behavior of Real Exchange Rates: Evidence and Implications. Carnegie-Rochester Conference Series on Public Policy 25, 117--214.

Obstfeld, M., Rogoff, K., 1994. The Intertemporal Approach to the Current Account. NBER Working Paper No. 4893.

Pesaran, M.H., Shin, Y., Smith, R., 1999. Pooled Mean Group Estimation of Dynamic Heterogeneous Panels. Journal of the American Statistical Association 94, 621--634.

Roubini, N., Wachtel, P., 1999. Current Account Sustainability in Transition Economies, in: Blejer, M., Skreb, M., (Eds), Balance of Payments, Exchange Rates and Competitiveness in Transition Economies, Kluwer.

Thoenissen, C., 2005. Current Account and Exchange Rate Dynamics and the Net Foreign Asset Position, in: Driver, S., Thoenissen, C., (Eds.), Exchange Rates, Capital Flows and Policy, Routledge, London.

Unayama, T., 2003. Product Variety and Real Exchange Rates: The Balassa-Samuelson Model Reconsidered. Journal of Economics 79(1), 41--60. 


\section{DAVIDSON INSTITUTE WORKING PAPER SERIES - Most Recent Papers}

The entire Working Paper Series may be downloaded free of charge at: www.wdi.umich.edu

CURRENT AS OF 3/13/07

\begin{tabular}{|c|c|c|}
\hline Publication & Authors & Date \\
\hline $\begin{array}{l}\text { No. 859: Real Exchange Rates in Small open OECD \& Transition } \\
\text { Economies: Comparing Apples with Oranges? }\end{array}$ & $\begin{array}{l}\text { Balázs Égert, Kirsten } \\
\text { Lommatzsch and Amina } \\
\text { Lahreche-Revil }\end{array}$ & Jan 2007 \\
\hline $\begin{array}{l}\text { No. 858: Is Education the Panacea for Economic Deprivation of } \\
\text { Muslims? Evidence from Wage Earners in India, 1987-2004 }\end{array}$ & $\begin{array}{l}\text { Sumon Kumar Bhaumik and } \\
\text { Manisha Chakrabarty }\end{array}$ & Jan 2007 \\
\hline $\begin{array}{l}\text { No. 857: Human Capital, Economic Growth, and Regional Inequality in } \\
\text { China }\end{array}$ & $\begin{array}{l}\text { Belton Fleisher, Haizheng Li and } \\
\text { Min Qiang Zhao }\end{array}$ & Jan 2007 \\
\hline $\begin{array}{l}\text { No. 856: Does Better Environmental Performance Affect Revenues, } \\
\text { Costs, or Both? Evidence From a Transition Economy }\end{array}$ & $\begin{array}{l}\text { Dietrich Earnhart and Lubomir } \\
\text { Lizal }\end{array}$ & Feb 2007 \\
\hline No. 855: Media Coverage \& Charitable Giving After the 2004 Tsunami & Philip Brown and Jessica Minty & Dec 2006 \\
\hline $\begin{array}{l}\text { No. 854: Default Rates in the Loan Market for SMEs: Evidence from } \\
\text { Slovakia }\end{array}$ & $\begin{array}{l}\text { Jarko Fidrmuc, Christa Hainz and } \\
\text { Anton Maleisch }\end{array}$ & Nov 2006 \\
\hline $\begin{array}{l}\text { No. 853: Monetary Policy before Euro Adoption: Challenges for EU } \\
\text { New Members }\end{array}$ & $\begin{array}{l}\text { Jan Filáček, Roman Horváth and } \\
\text { Michal Skorepa }\end{array}$ & Nov 2006 \\
\hline $\begin{array}{l}\text { No. 852: Private-Sector Credit in Central \& Eastern Europe: New } \\
\text { (Over) Shooting Stars? }\end{array}$ & $\begin{array}{l}\text { Balázs Égert, Peter Backé and } \\
\text { Tina Zumer }\end{array}$ & Nov 2006 \\
\hline $\begin{array}{l}\text { No. 851: Interest Rate Pass-Through in Central \& Eastern Europe: } \\
\text { Reborn from Ashes Merely to Pass Away? }\end{array}$ & $\begin{array}{l}\text { Balázs Égert,Jesus Crespo- } \\
\text { Cuaresma and Thomas Reininger }\end{array}$ & Nov 2006 \\
\hline $\begin{array}{l}\text { No. 850: Monetary Transmission Mechanism in Central \& Eastern } \\
\text { Europe: Gliding on a Wind of Change }\end{array}$ & $\begin{array}{l}\text { Fabrizio Coricelli, Balázs Égert } \\
\text { and Ronald MacDonald }\end{array}$ & Nov 2006 \\
\hline No. 849: Crime Distribution \& Victim behavior During a Crime Wave & $\begin{array}{l}\text { Rafael Di Tella, Sebastian Galiani } \\
\text { and Ernesto Schargrodsky }\end{array}$ & Nov 2006 \\
\hline $\begin{array}{l}\text { No. 848: Real-Time Time-Varying Equilibrium Interest Rates: Evidence } \\
\text { on the Czech Republic }\end{array}$ & Roman Horváth & Oct 2006 \\
\hline $\begin{array}{l}\text { No. 847: Financial Accelerator Effects in the Balance Sheets of Czech } \\
\text { Firms }\end{array}$ & Roman Horváth & Nov 2006 \\
\hline $\begin{array}{l}\text { No. 846: Central Bank Interventions, Communication \& Interest Rate } \\
\text { Policy in Emerging European Economies }\end{array}$ & Balázs Égert & Nov 2006 \\
\hline $\begin{array}{l}\text { No. 845: On the Role of Absorptive Capacity: FDI Matters to } \\
\text { Growth }\end{array}$ & Yuko Kinishita and Chia-Hui Lu & Nov 2006 \\
\hline No. 844: Current Account Sustainability in Selected Transition Countries & Aleksander Aristovnik & Nov 2006 \\
\hline $\begin{array}{l}\text { No. 843: Policy, Economic Federalism \& Product Market Entry: The } \\
\text { Indian Experience }\end{array}$ & $\begin{array}{l}\text { Sumon Bhaumik, Shubhashis } \\
\text { Gangopadhyay and Shagun } \\
\text { Krishnan }\end{array}$ & Nov 2006 \\
\hline No. 842: Price Mobility of Locations & Konstantin Gluschenko & Oct 2006 \\
\hline $\begin{array}{l}\text { No. 841: The Role of Foreign Direct Investment in the Firm Selection } \\
\text { Process in a Host Country: Evidence from Slovenia }\end{array}$ & Katja Zajc Kejzar & Sept 2006 \\
\hline $\begin{array}{l}\text { No. 840: Family Ownership and Control in Large Firms: The Good, The } \\
\text { Bad, The Irrelevant - and Why? }\end{array}$ & Mike Peng and Yi Jiang & Oct 2006 \\
\hline No. 839: Price Linkages of Russian Regional Markets & Konstantin Gluschenko & Sept 2006 \\
\hline $\begin{array}{l}\text { No. 838: The Effect of Pre-Primary Education on Primary School } \\
\text { Performance }\end{array}$ & $\begin{array}{l}\text { Samuel Berlinski, Sebastian } \\
\text { Galiani and Paul Gertler }\end{array}$ & July 2006 \\
\hline $\begin{array}{l}\text { No. 837: Do Investors Value Insider Trading Laws? International } \\
\text { Evidence }\end{array}$ & Laura Beny & Aug 2006 \\
\hline No. 836: How corruption Hits People When They Are Down & Jennifer Hunt & Aug 2006 \\
\hline
\end{tabular}

